\title{
A cristologia do Reino de Deus: contribuições para o diálogo inter-religioso
}

\author{
Orientador: Paulo Cezar Costa \\ Doutorando: Marcelo Batalioto \\ Área de Concentração: Teologia Sistemático-Pastoral \\ Linha de Pesquisa: Fé e Cultura
}

O pluralismo religioso, fenômeno marcante da época atual, pede à teologia estudos que tornem o diálogo inter-religioso mais operante. O paradigma exclusivista apresentou franco declínio, sobretudo, a partir do Vaticano II. Desde então diversas reflexões vem sendo postuladas. Destaca-se, pela sua constante incidência no atual cenário teológico, o paradigma pluralista, cuja intenção é atribuir valor e autonomia salvíficos às diversas tradições religiosas. Um aspecto bastante presente em algumas vertentes do referido paradigma é o relativismo. Afirma-se, sem mais, que todas as religiões são úteis e possuidoras da sua verdade. Busca-se, nessa vertente, um "dado comum", o "consenso geral", a "Realidade última", aquilo que pode ser partilhado por todas as religiões. Tal postura atinge o cristianismo quando sugere relativizar a singularidade de Jesus Cristo e a importância da Igreja. O caminho proposto por esta pesquisa consiste em assumir a singularidade de Jesus Cristo, e tudo aquilo que é essencial ao cristianismo, a partir da categoria Reino de Deus. Manifestado como grandeza teológica, escatológica e histórica, o Reino de Deus oferece um caminho promissor para o auto-entendimento do cristianismo em função do diálogo inter-religioso. Há elementos bem explícitos, observados a partir da cristologia do Reino, que possibilitam a elaboração de uma teologia adjetivada como teologia cristã em vista do diálogo inter-religioso.

Palavras-chave: Pluralismo religioso. Diálogo inter-religioso. Relativismo cristológico. 